\title{
BIJDRAGE TOT DE GESCHIEDENIS DER KARO-BATAKSTAMMEN.
}

\author{
DOOR
}

\author{
J. H. NEUMANN.
}

Een onderzoek naar de herkomst en het stamverband van de Karo-Batakstammen, stelt ons voor allerlei moeilijkheden, die men oorspronkelijk niet vermoed zou hebben. Deze moeilijkheden vinden haar oorsprong in de bronnen waaruit wij onze kennis moeten putten, teneinde een inzicht te ontvangen omtrent het verband waarin de stammen onderling staan, en de herkomst der stammen. De bronnen die te onzer beschikking staan, zijn vooral de stamverhalen, verder de taal, en dan het verschil of de overeenkomst van gebruiken en zeden. Schrijver van deze regelen is zich zeer wel bewust van het moeilijke van zijn taak, maar daar tot heden nog niet geprobeerd is de uiteenloopende verhalen tot een eenheid te verwerken, gezien ook hoe men maar steeds op de oude voorstellingen voortbouwt, meende hij zijn langzamerhand verkregen opinie en beschouwing omtrent de geschiedenis van dit volk, niet achter te mogen houden. Laten anderen deze gegevens aanvullen en verbeteren.

\section{I.}

Meent men bij de gangbare voorstelling over het Karovolk een eenheid voor zich te hebben, bij dieper navorschen ontdekt men dat er zich een veelheid voordoet, die aanvankelijk verbijsterend werkt. Deelde men dit volk vroeger zoo rustig in in vijf stammen, thans blijkt dat, al moge de afstamming stellig tot een gemeenschappelijk stamland terug te brengen zijn, de weg tot de hedendaagsche bestaande verhoudingen niet volgens een eenvoudig plan is gegaan. Wij hebben hier te doen met een groote verscheidenheid van stammen, die van verschillende zijden het land zijn ingetrokken, vreedzaam of als veroveraars, maar die zich later door middel van het stichten van federaties (oeroeng) Dl. 82. 
tot een min of meer samenhangende eenheid verbonden hebben. Stammen als de Karo-karo, de Ginting, de Simbiring, die zich thans vrijwel als eenheid beschouwen, blijken bij nader onderzoek, ook weer te bestaan uit verschillende onderdeelen, welke later zich tot een eenheid verbonden hebben.

Bekend is het dat de Karo-bataks zich zelf beschouwen als te bestaan uit de vijf stammen (merga) Karo-karo, Ginting, Taringan, Simbiring en Peranginangin. Een verhaaltje vertelt ons, dat deze namen de namen zijn van vijf broeders, allen zonen van één vader, Nini Karo geheeten. Gaat men nu de stamverhalen na, dan komt men tot de conclusie, dat dit verhaaltje de zaak wel wat heel eenvoudig voorstelt en wel een zeer jonge verklaring moet zijn betreffende den toestand van de laatste jaren. Thans vindt men een uitgestrekt gebied door een volk bewoond, dat zich, afgezien van alle stamverschillen, tot de Karo-Bataks rekent, in tegenstelling met Pakpak- en Timoer- of Toba-Bataks. Geheel het samenstel van de Karo-Batakstammen is verbonden door één dialect, dat overal verstaan wordt en weinig afwijkingen onderling vertoont. De Karo's van Langkat, Deli, Serdang en de Hoogvlakte tot de Alaslanden toe, zijn verbonden met elkaar door één taal. Dit is wel een punt om even bij stil te staan, want een dialect dat zulk een groote oppervlakte als het ware bedekt, moet toch weer terugwijzen op een gemeenschappelijke herkomst van al deze verschillende stammen. En waar de afwijkingen van zulk een geringe beteekenis zijn, daar moeten wij aannemen dat of dit volk nog niet zoo lang geleden uit zijn stamland gekomen is, of dat er een groot verkeer bestaan heeft tusschen al de genoemde plaatsen. Immers die eenheid van taal zou zeker niet mogelijk zijn, zonder nauwe aanraking met elkaar. En in het vervolg zullen we dan ook zien, dat de beide genoemde mogelijkheden wel juist zullen zijn. De komst in het Karoland kan nog niet in een ver verleden liggen en aanraking tusschen de stammen onderling is er zeker ook veel geweest.

Een tweede vraag is die naar den naam der vijf stammen. Stellig moeten de vijf stammen verwant aan elkaar geweest zijn en de later er bij gekomenen hebben zich in het stamverband gevoegd. In de verhalen komt wel uit dat de echte Karo's en de Gintings reeds het land bezaten voordat de andere stammen hun intocht hielden.

Wat bewoog nu deze menschen hun stamland te verlaten en 
naar de tegenwoordige Karolanden te trekken? Wij kunnen hierop geen antwoord geven, al zullen de hieronder volgende beschouwingen wellicht een weinig licht over deze zaak verspreiden.

Wij kunnen slechts veronderstellen, dat er een "trek» geweest is van de Pakpaklanden uit naar de Karolanden, dat deze trek nog zoo heel lang niet geleden heeft plaats gehad en dat deze trek niet voor alle stammen tegelijkertijd heeft plaats gehad.

II.

Toen de tegenwoordige bewoners het land binnenkwamen, waren toen de Hoogvlakte, en de doesoens van Deli, Serdang en Langkat door andere volken bewoond? -- Het is natuurlijk dat deze vraag bij ons opkomt. Verschillende redenen dwingen er ons toe. Allereerst deze, dat men verschil maakt tusschen Kare-sekali, "de echte Karo» en de Karo-karo. De echte Karo, die zich met trots $\mathrm{Ka}$ ro-sekali noemt, dus niet behoort tot het allegaartje van de andere Karostammen, bewonen nog maar één dorp, en nog wel maar eene wijk van dat dorp, nl. Siberaja. Zij zijn de echte Karo en de anderen zijn Karo-karo. de bij de Karo-wonenden of de op de Karo-gelijkenden. De eerste vertaling lijkt mij de juiste, daar de menschen van de Goenoeng-goenoeng, het hooger gelegen gedeelte van de Hoogvlakte, waar thans de Karos wonen, kortweg $\mathrm{K}$ a ro noemen. $\mathrm{Z}_{\mathrm{ij}}$ spreken van i $\mathrm{Karo}$ als ze zeggen willen, waar iemand thuis behoort.

Wij kunnen dus aannemen dat het land aldaar, voordat de Karo-karo er woonden reeds Karo heette. Hoe ver zij er het land in beslag genomen hadden, weten we niet. Een verhaal, dat mij gewerd van Samosir, verhaalt, dat er in het landschap Oerat, kampong Sirait, een kleine Harostam woont. Deze stam is afkomstig van Karo, en is uit het Karoland naar Samosir getrokken. De stamvader had drie zonen, waarvan er een Radja Haro heette, die vanuit Tamba naar Asahan ging. Een andere zoon heette Moentē Haro, wat ik vertaal met Moentē uit het Karoland of de Karosche Moentē. Bovendien had hij een slaaf si Tangkal taboe-taboe, dus een mensch (of een stam) die in hoorigheidsverhouding tot hen stond, maar die later door de broeders tot hun broeder verklaard werd; dus in den stam werd opgenomen. Verder vermeldt het verhaal een sterken buffel 
waarvan later bij de Gintings nog meer zal vermeid worden.

Er schijnt dus werkelijk op de Karohoogvlakte een stam gewoond te hebben, die zich Karo noemde en die zoowel aan de taal, als aan de streek zijn naam gegeven heeft. Thans is deze stam nog maar beperkt tot één dorp, waarvan het grootste gedeelte bewoond wordt door Simbiringstammen; hij heeft een zeker aanzien, wat wellicht een herinnering is aan betere tijden die hij gekend heeft. Wellicht dat het thans door de Karo-karo bewoonde gebied eens zijn rijk geweest is, geestelijk heeft het echter dan toch de overwinning behaald, doordat de binnendringende stammen zich naar hem noemden en zijn taal aannamen.

III.

In Deli, Serdang, Langkat en verspreid over de Karohoogvlakte, vindt men steenen kamers, misschien grafkamers, waarvan de meest bekende wel de Batoe Kemang of Batoe Oemang van Doerintani (Simbahē) is. Wie zijn de makers van deze kamers geweest? De tegenwoordige bewoners stellig niet, zij schrijven ze toe aan de oemangs. En het is ook niet aan te nemen dat de wijze van begraven in steenen kamers verloren zou zijn gegaan; begrafenisgebruiken behooren mede tot de langst levende. Neen, de tegenwoordige bewoners hebben deze steenen kamers weer in de bosschen ontdekt. Maar van welk steenhouwendvolk zijn ze dan afkomstig?

Ik ben geneigd de verhalen van de oemangs niet heelemaal naar het rijk der fantasie te verwijzen. Zeker, een verwijzing naar de dwergen en kabouters zou ons gemakkelijk uit het veld doen slaan, maar de mogelijkheid is niet uitgesloten, dat men verhalen van de oemangs op een ander volk heeft overgebracht. Men verhaalt van de oemangs, dat zij menschen waren, alleen liepen zij met naar beneden gekromde teenen, zoodat de bovenzijde der teenen bij het loopen den grond raakte. ( $\mathrm{Zij}$ liepen dus niet met achterwaarts gekeerde voeten). Dit zou ons aan een aapsoort of ander dier doen denken. Hoort men echter de verhalen van deze oemangs, dan krijgt men den indruk van een volk dat een zekere cultuur bezat. In Adjinembah, bij het Tobameer, woonde een oemang in het dorp, die gehuwd was met een dochter van den vorst. Deze oemang bezat een gouden lamp. Later trok hij het dorp uit en begaf zich met zijn vrouw naar den berg Boeatan. - De oemangs waren ook goede 
bouwmeesters en konden in korten tijd huizen bouwen. Het waren toovenaars, die het overdag konden doen duister worden. $\mathrm{Ze}$ voerden onderling oorlog en roofden ook menschen. Beschouwt men nu den steen van Doerintani, dan ziet men aan de uitvoering en aan het ornament bij den ingang, dat kunstzin aan de bouwers niet ontbrak. Een der voorvaderen van de Ginting vond in zijn strik (om wild te vangen), een dochter van den radja oemang, die uit den hemel was gevallen, en huwde met haar.

Wie waren deze menschen, die men als oemangs betitelde? We weten het niet. Zijn zij de Karo-sekali geweest? Of waren zij er lang voor de Karo-sekali? Ook hierop weten wij geen antwoord. Ook een door mij gevonden koperen hamertje wijst op een cultuur, die zulke voorwerpen wist te hanteeren of te vervaardigen.

IV.

De hierboven gegeven algemeene beschouwingen meende $\mathrm{ik}$ te moeten laten voorafgaan, teneinde den lezer een draad in handen te geven aangaande de verdere bijdragen, zoodat men eenigszins den weg zou kunnen volgen in den doolhof van die stammen, en weten zou in welke richting ons onderzoek zich beweegt. Meer dan hierboven vermeld is, weten wij niet wat den stam der Karo-sekali aangaat; wij gaan dus maar dadelijk over tot de stammen der Karo-karo en wat hunne verhalen vertellen over hun geschiedenis. Wij bespreken dus allereerst de Karo-karo, "de op de Karo gelijkenden».

Het gebied dat de Karo-karostammen thans bewonen, wordt begrensd ten Oosten door het randgebergte dat de Hoogvlakte van Serdang scheidt. Ten Zuiden ongeveer door de Biangrivier (na zijn doorbraak in Langkat de Wampoerivier geheeten), ten Westen door den berg Sinaboen en ten Noorden strekt het zich uit tot in de laagvlakte van Deli en Serdang. Deze stammen noemen zich allen Karo-karo, en beschouwen zich als bloedverwant. Waar zij wonen, maken zij verschil tusschen eigenaars van den grond ( $\mathrm{si}$ mada $\mathrm{taneh}$ ) en de bijwoners, de geregeerden ( $g$ in e $\mathrm{mgem}$ ). Wij hebben hierin een criterium om de oorspronkelijke veroveraars of ontginners van den grond, van de later daarheen verhuisden te onderscheiden. Wanneer wij in het vervolg dus spreken van het gebied van den stam, dan 
hebben wij dien stam op het oog, die de eigenaars van den grond genoemd worden. Andere stammen kunnen nooit rechten op grond daar bezitten, tenzij tijdelijk.

Wanneer wij iemand van een der vijf hoofdstammen naar zijn stam vragen, dan noemt hij eerst zijn hoofdstam, dus bij deze stam zegt hij dat hij een Karo-karo is. Vervolgens vraagt men bij elke begroeting: Welke Karo-karo ben je? Hij antwoordt dan met de sub-merga te noemen, bijv. Baroes. Wij weten dan, dat hij een Karo-karo Baroes is. Dus een Baroes'sche Karo-karo. Het is noodig deze onderafdeeling (sub-merga) te weten, want er zijn vele Karo-karos, en tevens blijkt hieruit, dat men onder elkaar ook niet onverschillig is voor deze sub-mergas. Toch beschouwen alle Karo-karos zich als bloedverwant, wat hieruit blijkt dat huwen onder elkaar verboden is. Men beschouwt dit als bloedschande. Dit laatste nu kan een bepaling van ouden datum, en de herinnering zijn aan een gemeenschappelijke afkomst; het kan ${ }_{\text {sook }}$ het gevolg zijn van het te zamen wonen met de oorspronkelijke Karos, die zulk een huwelijk in den stam niet dulden wilden. Er zijn voorbeelden, dat de nood drong dit verbod te overtreden (Goeroesinga).

Meende ik vroeger dat de naam der hoofdmerga (merga si lima "de vijf stammen») voldoende was om een onderzoek in te stellen, al ras bleek, dat elke merga een samenstel van stammetjes was, en dat de namen der sub-merga van zeer veel belang waren voor het onderzoek. De naam der sub-merga geeft ons vaak een draad in handen om den uitgang uit het labyrinth te vinden. Wij zullen dus beginnen, zoover als taal en verhalen ons den weg wijzen, het een en ander te verhalen van de stammen die tot de Karo-karostam behooren, en vervolgens de vier andere stammen ook zoo behandelen.

\section{V.}

$$
\text { De Karo-karo. }
$$

Een van de Karo-karostammen noemt zich de Karo si noe Raja. Wij zullen dit vertalen met Rajasche Karo-karo. Zij beweren afkomstig te zijn van Katoe Osang in de Pakpaklanden. Thans zijn zij gevestigd in de Adji-dorpen van Soekapiring, in Boenoeraja en Singamanik. Allereerst hebben zij zich gevestigd in de Adjidorpen. Vandaar trokken de drie broeders eens op de 
jacht en vervolgden een bamboerat (pedi). Zij kwamen toen in het landschap Goenoenggoenoeng en vonden het land zoo schoon dat zij zich daar vestigden in Rioeng en Singamanik. Later gingen zij zich nog verderop vestigen in Radja Berneh, maar daar zijn zij weer vertrokken of verdreven. ${ }^{1}$ )

Dat zich vestigen of veroveren van Singamanik zal wel een strooptocht geweest zijn. Singamanik zal wel reeds bestaan hebben, want de naam behoort tot de submerga van den Gintingstam. Singa en manik zijn beiden submerga van de Gintings en zullen wel eerst het land bezeten hebben, daar dit dorp in het gebied van de Gintings ligt. Ook de thans daar nog wonende Ginting-manikstam wordt als de schoonvader van de Rajas beschouwd. Het ligt voor de hand dat na de verovering van Singamanik door de Rajas, waarbij zij zich vermoedelijk de vrouwen der Gintings hebben toegeëigend, een vredesluiting volgde, waarbij de Ginting-manik later als schoonvader (kalimboeboe) erkend werd.

Van uit Singamanik moeten de Rajas het dorp Boenoeraja gesticht (of veroverd) hebben. De naam is onverklaarbaar in het Karosch, vandaar dat ik de gissing waag dat het $\mathrm{B}$ a n o e a $\mathrm{Raja}$ oorspronkelijk geweest zal zijn.

De bezetting van Singamanik moet ongeveer vijf geslachten geleden hebben plaats gehad, dus omstreeks het jaar 1770. Voor dien tijd woonden daar reeds de Gintings, en de Rajas woonden toen reeds in Soekapiring. Het schijnt dat de Rajas een krijgshaftige stam geweest zijn. Ik leid dit af uit nog twee namen waarmede zij zich benoemen, n.l. Kemit en Djoeng. Beide woorden zijn mij in het Karosch niet bekend, maar wel uit het Tobasch. Wij lezen in het woordenboek van Dr. Warneck manghomit «beherrschen, und zwar Leute, die aus eine anderen Gebiet gekommen sind»; djoeng zouden wij dan in verband mogen brengen met djoengdjoengan kder Hervorragendste, Anfuhrer.» Ook de naam Raja duidt al grootheid aan.

Op de Hoogvlakte treft men Raja thans in de macht van de Karo-karo Pouba, ook in eenige kampongnamen aan. Raja een dorp niet ver van Berastagih gelegen, Boenoeraja dat we als banoea raja beschouwen en Siberaja een van de grootste kampongs van de Hoogvlakte.

1) De thans in de adji-dorpen wonenden noemen zich Karo-karo si noeadji. 
Onwillekeurig denken we ook aan de Raja van Simeloengoen; nog in historische tijden was dat volk de schrik van het Batakland. De naam van toehan Rondahaim is ons door Westenberg overgeleverd als een machtig vorst. Maar veel helpt dit ons niet, daar in Pematang Raja thans een Gintingvorst regeert en als bewoners ook veel stammen opgegeven worden die we alleen onder de Gintingstammen kunnen rangschikken (Damoentē, Manik, Seragih enz.). Wij bezitten ook geen gegeven dat wij zouden kunnen bewijzen dat zij uit Simeloengoen gekomen zouden zijn.

Wel is opvallend dat zij den adellijken titel van Sibajak niet gekend hebben en de tegenwoordige Sibajak van Boenoeraja heeft dien titel langs een omweg verkregen. De pengoeloe van Boenoeraja (pengoeloe «dorpshoofd») huwde met een gescheiden vrouw van den Sibajak van Baroes Djahē. Deze vrouw bracht een zoon mede, dus een Sibajak van geboorte. Toen hij groot was nam hij den stamnaam van zijn vader aan en behield tevens den titel Sibajak, aldus was er ook een Sibajak Karo-karo Boenoeraja ontstaan.

VI.

De Karo-karo Sitepoe.

Een van de meest volkrijke streken is de streek waar de Sitepoe zich gevestigd hebben. Hun gebied ligt om den berg Sinaboen heen, waar de groote dorpen Naman, Berastepoe enz. zich bevinden. De stamnaam Sitepoe geeft niet veel licht. « Het is een héester in jong bosch, die bij het ontginnen gespaard wordt, omdat men de bladeren, gekookt, eet. Blaoxylon longifolium Miqu. fam. Euphorbiaceae». (Opgave van den heer Lörzing ontvangen). Misschien ook dat de dorpsnaam verband houdt met een rijstsoort berastepoe.

Volgens hunne opgaven zijn zij afkomstig van Toba(?) nl. van Sihotang. Het is merkwaardig, dat de Simbirings die in Perbesi wonen, en waar vroeger ook de Sitepoe gewoond hebben, ook opgeven van Sihotang te komen. $\mathrm{Zij}$ waren echter daar maar ginemgem (bijwoners), geen eigenaars van den grond. Een aardige bijdrage over de afkomst van de Simbiringstammen Dēpari Berahmana en Moeham (welke te Perbesi wonen).

Het dorp Perbesi moet vroeger ook door de Sitepoe bewoond 
zijn geweest, zij moeten het zelfs gesticht hebben. Maar de Perangin-angin Sibajang, ook wel Pintjawan geheeten, verdreven hen vandaar. Volgens de verhalen ging dat vreedzaam in het werk. De Sitepoe verhuisden naar Naman (Teran). Men makkte een verbond met elkaar en beschouwde elkaar voortaan als van één familie te zijn. Wederzijds mocht men geen huwelijken met elkaar aangaan, zelfs mocht men elkaars stamnaam overnemen. De Sitepoe namen van Perbesi een boompje mede, een gerat (een zekere manggasoort, Joustra) en plantten het te Naman. Daar moet de boom nog bekend zijn onder den naam Gerat Perbesi. Zij lieten ook cocospalmen achter, die den naam droegen van Toealah Teran. Deze bestaan thans niet meer.

Indien dit verhaal waarheid bevat, dan heeft de inval van de Perangin-anginstam Sibajang nog geen 100 jaar geleden plaats gehad. De Sitepoe woonden toen reeds in Perbesi. Het is tevens een bewijs dat de Karo-karostammen steeds noordelijker getrokken zijn. Thans bewonen zij het land oostelijk van den Sinaboen gelegen in de richting van den Sibajak.

\section{VII.}

\section{De Karo-karo Baroes.}

Wanneer wij ons nu naar de oostelijke zijde van de Hoogvlakte begeven, dan komen wij in het gebied van de Karo-karo Baroes. Zij bewonen voornamelijk wat thans heet Si VII koeta.

Aan de komst van dezen stam is een persoon verbonden, die den naam droeg van Si-mbelang-tjoeping «Grootoor». Zijn ooren waren zoo lang, dat het eene hem als slaapmat diende en het andere hem als deken. Dus nogal kenbare teekenen. Hij komt uit Osang, evenals de Rajas. In een verhaal van de Gintings van Adjinembah komt hij voor als een groot helper in den nood.

De dochter van den vorst van Adjinembah, Si Beroe Goengoenen geheeten, is gehuwd met een oemang. Deze oemang heeft een huis gebouwd voor den radja, van zeven roeang (14 gezinnen). Tegen den wensch van den oemang in, gaf de vorst toch een huisinwijdingsfeest (bengket roemah). Uit wraak liet de oemang het zeven dagen lang duister worden. Al dien tijd konden de gasten niet huiswaarts gaan en was hij verplicht hen te eten te geven. Zelfs de buffel si Langga loetoe moest eindelijk geslacht worden om aan toespijs te komen voor al die menschen. 
Toen nu de vorst zat te peinzen, hoe hij verder nog moest voorzien in het eten voor zijn gasten, kwam iemand hem vertellen dat er buiten het dorp een onbehoorlijk mensch was (kalak soembangsoembang vertaal ik hier met onbehoorlijk, in den zin van anders dan anderen, vanwege zijn groote ooren). Deze mensch had in dagen niet gegeten. Of hij naar het dorp mocht komen? Hij zou den vorst misschien wel uit den nood helpen. Deze man was Grootoor.

Hij kwam naar het dorp, en hielp den vorst de duisternis verdrijven zoodat de gasten konden huiswaarts gaan. De oemang had het dus afgelegd tegen de tooverkunsten van Grootoor.

$\mathrm{Na}$ het feest vestigde Grootoor zich in de streek van het tegenwoordig Belagen in si VII Koeta, en leefde van de jacht. Telkens wilde de vorst van Adjinembah hem opzoeken, maar slechts door een list, door zijn hond te volgen, gelukte hem dit. Naderhand brachten zij elkaar over en weer bezoeken. Mede met zijn hulp werden de Gintingdorpen Dokan en Koeboe gesticht.

Grootoor trok steeds meer naar het Noorden en stichtte Baroes Djoeloe, een thans verdwenen kampong, vlak bij het tegenwoordige Baroesdjahē. En nog verder trok hij, de tegenwoordige doesoens van Deli in, en stichtte de kampong Simēmē, dicht bij het tegenwoordige spoorwegstation Batoe. Vlak bij de kampong is nog onlangs een steenen bord opgegraven, een z.g. pinggan pasoe.

Toen hij rijk geworden was, trok hij naar Atjeh, om er een pangkat te halen. Hij huwde daar een Atjehsche vrouw en kreeg er een kind bij. Al de afstammelingen uit dit huwelijk zijn Mohammedaan geworden.

Uit zijn Bataksche vrouw kreeg hij een zoon en twee dochters. Deze zoon is Sibajak geworden van Baroesdjahē. De tegenwoordige Sibajak van Namo Soero (Deli) is zijn afstammeling in de negende generatie. $\mathrm{Zijn}$ naam was si Nangking en hij had zeven kinderen, waarom nu nog gesproken wordt van si VII Koeta, de zeven dorpen. De namen der afstammelingen worden opgegeven als volgt:

Djamboer ligë, welker afstammelingen Sibajak werden. Regeeren in Namo Soero (Simēmē is doesoen geworden van Namo Soero).

Roemah si beras. $\mathrm{Zij}$ werden pengoeloe. Regeeren in Biroebiroe, Oedjoeng sinembah en Namo Serit.

Roemah si gedang. Pengoeloe in Sinembah. 
Baroes si nering. Pengoeloe Tandjoeng Ngoeda. Op de Hoogvlakte Serdang, Penampēn en Siberteng.

De twee meisjes werden uitgehuwelijkt aan den pengoeloe Rambē (Moentēstam), deze is dus anak-beroe van de Baroes. En de tweede huwde met den pengoeloe van Namo Rindang, een Perangin-angin.

Men zegt dat die grootvader 230 jaar oud geworden is. Dat zal wel zoo verstaan moeten worden, dat het ongeveer zoo lang geleden is, dat hij het Karoland introk. Negen generaties van ongeveer $2 \bar{j}$ jaar brengt ons tot dit getal. Wij hebben hier een zekeren houvast door den persoon van Grootoor. Stellig mogen wij hem beschouwen als een aanvoerder, die met zijn Baroesstam naar het Karoland getrokken is. Zij kenden den titel van Sibajak, daar de vorst van Baroesdjahē, zijn afstammeling, den Sibajaktitel voert. Stellen we de invasie der Baroes omstreeks 1700, dan zijn zij vóór de Rajas het land ingekomen, want bij de stichting van Boenoeraja wordt het bestaan der Baroes al verondersteld.

Of verder onderzoek naar den naam $\mathrm{Djamboer}$ ligē nog meer licht zal brengen? Een djamboer ligē is een speciale bouwwijze van een djamboer (vreemdelingen en jonggezellenverblijf) voorzien van vier toerē (galerijtjes). Te Baroesdjahē en te Soeka (Ginting) staat zulk een djamboer.

Wie Grootoor geweest is zullen we wel niet meer te weten komen. Maar al zijn zijn ooren niet van zulke kolossale afmetingen geweest als het verhaal vermeldt, toch zal hij wel zulk een kenteeken gehad hebben, zoodat hij in de oogen der menschen een bijzonder gelukkig persoon was. Er bestaat thans nog een persoon met kolossale lippen, si kapal biber in de wandeling geheeten; tegen zulke personen wordt opgezien, vooral als zij dan nog andere capaciteiten bezitten. Van de Simpiring Kembaren beweert men dat alle vrouwen bijzonder kleine oorlellen hebben, wat men niet schoon vindt. Op vele tooverstaven en perminakans vindt men gesneden koppen met bijzonder lange oorlellen; achtte ik dit vroeger alleen een versiering, thans houd ik dit voor een bepaald schoonheids motief. Ook bij menschen van het eiland Samosir is het mij opgevallen welke kleine of bijna geen oorlellen zij hebben. Aan meer bevoegden hier een verder onderzoek in te stellen, of wij hier met een rassenkenmerk te doen hebben. Grootoor is in elk geval aanvoerder geweest van de Baroes 
en heeft si VII koeta en een groot deel van de benedenlanden bevolkt. Of hij dit land op anderen veroverd heeft, weten wij niet. Of hij werkelijk in Atjih geweest is of dat hij de kustMaleiers er voor gehouden heeft, ook niet. Wel blijkt ons in de verhalen dat de Gintingstam reeds op de Hoogvlakte in Adjinembah woonde en oemangs waren er ook nog. Thans is de Sibajak van Baroesdjahē een viervorst, welken titel men aan Atjihschen invloed toeschrijft.

Aangaande de Karo-karo Lingga staat vast dat zij afkomstig zijn van Lingga Radja in het Pakpakland. Nog steeds onderhouden zij betrekkingen met hun dorp Pakpak. Bij hun komst in het land was alles nog bosch en moesten zij vooral van de jacht leven. Teran, Sarinembah en XII koeta bestonden reeds, zoodat zij wel tot de laatst aangekomenen behooren. Later kwam er zich nog een Sibajak uit Lingga Radja vestigen en ook een Sibajak Nodi, een streek aan de Laoe Renoen bij Laoe Baleng. Ook hier onderscheidt men een veroeng pengoeloe en de oeroeng persilihi (Sibajaks). Tot de Sibajaks behooren Lingga, Soerbakti en Gadjah.

De heerschers in XII Koeta zijn de Karo-karo Poerba. Men schrijft hun herkomst toe aan weggeloopen slaven uit het rijkje Poerba. Het zijn dus waarschijnlijk Tarigens die zich Karo-karo zijn gaan noemen.

VIII.

De Gintingstammen.

Het gebied van de Gintingdorpen ligt in een terrein dat begrensd wordt door den berg Piso-piso en het Wilhelminagebergte ten zuiden en de Biangrivier ten noorden. Naar het westen toe komt het Karodorp Singamanik er in te liggen, benevens het Simbiringdorp Sarinembah. In het oosten grenst het aan het Tarigangebied van Nagasariboe.

Ook hier geldt wat wij van de Karo-karostammen gezegd hebben, de Ginting zijn geen eenheid, maar onderscheiden zich weer in afzonderlijke stammen. $\mathrm{Zij}$ voelen zich echter allen verwant en vandaar is huwelijk in den stam verboden, geen Ginting mag met een Ginting huwen. Hun taal is dezelfde als die van 
de Karo-karo, dus het Karo-Bataksch, al zijn er enkele verschillen vap geen beteekenis. Men onderscheidt drie voorname groepen in dezen stam, nl. de G. si ni Soeka, de G. Manik en de G. Moentē. De Soekasche Gintings onderscheiden zich weer in negen ondergroepen, vandaar ook hun naam Ginting, si siwah sada Ginting, de negen Gintings die een zijn. Indien het bij de Karo-karos reeds vermelde verhaal van ouden datum is, dan zijn de Moentē reeds lang in het land geweest, en rijst de vraag of wij hier weer niet hetzelfde geval hebben als in de Karostreek, dat nl. een Gintingstam reeds lang dit gebied bewoond heeft en de andere stammen, die naar deze streek verhuisden, bij de Gintings zijn ingelijfd en aldus zich ook Gintings zijn gaan noemen, maar hun oorspronkelijke merga als sub-merga zijn blijven voeren. In het dorp Djoehar wonen Gintings, Perangin-angins en Tarigans bij elkaar, waarover later meer.

Uit de verhalen leeren wij, dat de Gintings langs twee wegen het land zijn binnengekomen. De Ginting Soeka geven op langs La oe Lingga, dus over het Siboeatangebergte het land te zijn binnengekomen. Zij kwamen uit Tind in het Pakpakland. Van Laoe Lingga hebben zij zich via Soegihen oostwaarts naar Soeka en westwaarts naar Djoehar uitgebreid.

De Ginting Moente moeten over het meer gekomen zijn, en via Tengging, Adjinembah zich naar Moentē en Keriahen begeven hebben. $Z_{\text {ij }}$ zijn afkomstig van Kalasen in Pakpak, gingen eerst naar Samosir, naar Pangoeroeran, toen naar Tamba, vervolgens naar Paropo en daarna naar Tengging, Adjinembáh of Adji si nembah geheeten, zooals reeds boven vermeld is. In de Pakpaklanden vermeldt Ypes een Radja Lela te Boetar van de merga Moentei.

Vanwaar de Ginting Manik het land binnenkwamen is mij nog niet duidelijk. In Simeloengoen (Siantar) is de Manikstam met vele sub-mergas (volgens Tideman) een zeer belangrijke, die allen beweren van Samosir afkomstig te zijn. In de Pakpaklanden vermeldt Ypes dat de grond aan den linkeroever van de Tjinendang oorspronkelijk behoorde aan de merga Manik. En in het rijkje Binang noemt hij een merga Manik.

Aangaande de Ginting Soeka wordt vermeld, dat zij afkomstig zijn van Simbolon op Samosir. Vandaar trokken zij verder naar Kalasen en toen over het gebergte naar Soegihen, van Søegihen 
naar Goeroe Benoea, hun tegenwoordig gebied. Te Goeroe Benoea werden de tien Gintings geboren. $\mathrm{Zij}$ waren elk in een vlies gehuld en geleken op een goend oer (soort komkommer, Benincasa ceritera Savi). De legendarische goeroe Pakpak, die daar voorbij kwam, wist de menschen te helpen en toen kwamen er negen jongens en een meisje te voorschijn. Deze negen zonen waren de stamvaders van de tegenwoordige Ginting Soeka en heetten: Soegihen, Goeroe Benoea, Seragih, Sapah, Babo, Garamata, Djawak, Goegoeng, Soeka. Een oude poestaka noemt de volgende namen: Babo, Goeroepatih, Soeka, Beras, Djadi, (of Adji) Dibata, Soegihen, Boekit, Garamaba, Djertamboen. Babo was de jongste en Djertamboen de oudste. De vader van deze kinderen stichtte het dorp Soeka. De meeste zijn dorpsnamen in de Gintingstreek, behalve Seragih, Sapah en Garamata. Het meisje si Bembem geheeten ligt begraven op de markt Bem Bem.

De Sibajak van Soeka legde er vooral den nadruk op, dat Soeka en Goeroe Benoea broeders zijn.

Het dorp Kidoepen, waar Perangin-angin van Djoehar, Gintings van Adjisinembah en Simbiring Malēala wonen, heette vroeger Pertoempoeen, omdat hier indertijd deze drie stammen samenkwamen.

In de verhalen van de Gintings komt vaak voor een groote buffel, kerbo si langga loetoe of kerbo si nangga loetoe geheeter. Ergens aan den berg Siboeaten moet men nog den pas aanwijzen waarlangs de buffel neerdaalde, het land inkwam.

In een verhaal wordt vermeld dat de zoon van den vorst van Adjinemba vergezeld van zes slaven, naar Raja (Simeloengoen) toog. De vorst aldaar was zijn ma ma (oom van moederszijde) en hij trouwde met zijn dochter en werd zoo vorst van Raja. Deze zoon heette Radja Sorē en was een Ginting Moentē. In het land der Tarigans werd dus een Ginting Moentē de vorst. De reuzenbuffel moet te Raja in een rots veranderd zijn. In een ander verhaal, waar hij Radja Sori heet, wordt gezegd dat hij later naar Adjinembah terugkeerde en voor zijn vader een prachtig huis op den berg Pertjinahen (of Osar) bouwde. Door bij dit feest bij gebrek aan andere buffels ook de kerbo si langga loetoe te slachten, verdween het geluk van zijn huis. Adjinembah werd door Soeka overwonnen en staat sedert onder den Sibajak van Soeka. 
Heeft deze buffel of buffels eenige beteekenis voor ons doel? De naam is uit het Karosch, voor zoover mij bekend, niet te verklaren, maar uit het Tobasch wel. Morlangka "loopen, gaan en mangaloetoei "vervolgen». Zijn het vechtbuffels geweest? Zijn zij in den oorlog gebruikt? Of waren het de Gintings die de buffels voor het eerst invoerden? Voor dit laatste is wel wat te zeggen. In de meer genoemde Ginking-poestaka (van Boeloeh Pantjoer) komt o. a. ook voor, dat er plotseling voor den Sibajah van Lajo Lingga, die gehuwd was met de hemelsche oemangdochter, dertig buffels van den berg Poedjan afkwamen. Vanwaar weet men niet. Bij de grondbewerking wordt toch in de Goenoeng-goenoeng veel meer van de ploeg gebruik gemaakt dan in de Karo-streek, waar men nog zeer veel de omwerking van den grond met lange stokken verricht (ngengkal). Ook in Si lima senina, uit Si Antar afkomstig, doet men dit.

Nog êen andere opmerking naar aanleiding van dit verhaal. Indien de vorst van Raja de mama was van Radja Sori, dan was zijn moeder stellig een Tarigan. Er is dus reeds in dien tijd een verband tusschen Tarigan en Ginting.

Door de Gintings van Adjinembah wordt ook een verklaring gegeven aangaande het ontstaan van het tandenvijlen. Wegens het voortdurend stelen van djagon (mais), ging men er toe over de tanden van de slaven te vijlen. Daar men het mooi vond, vond het ook navolging bij de anderen.

Een andere merga Ginting, is die van Singa, wonende in het dorp van dien naam. $\mathrm{Zij}$ moeten verwant zijn aan de Moente, Seragih en Manik, niet met die van Soeka.

Wanneer we een en ander nog eens aan ons voorbij laten gaan, dan krijgen we den indruk, dat de G. Soeka wel de jongste invasie geweest is, die ook Adjisinembah ten onder bracht. De naam Seragih is ook bekend als een groote stam in Simeloengoen. In een zendingsbericht, dat ik niet meer bij de hand heb, meen ik van een doodenfeest gelezen te hebben waarbij een soort godin Seragih op een wagen werd rondgereden. Misschien dat iemand daar nog nader bericht over weet te geven. Het moet toch wel iets beteekenen dat men in de verhalen telkens op een meisje stoot, vgl. het hieronder te vermelden bericht over het meisje van de S. Kembaren.

Over den verdwenen Gintingstam Pase, zal bij de Sibirings gehandeld worden. 
Het is ook niet van belang ontbloot hier opmerkzaam te maken op de graven van meisjes die op enkele markten voorkomen. Mij zijn drie markten bekend waar een meisje begraven ligt. De verhalen zijn alle eensluidend, nl. om de een of andere reden gaat het meisje dansen, totdat zij in den grond wegzinkt of zooals bij de markt Goenoeng Meriah in Kembaren: het meisje wordt gedood. Deze verhalen gaan omtrent een oude markt bij Lingga, de markt Bembem en die in de Kembarenstreek.

Onwillekeurig gaat men denken aan een menschenoffer dat er noodig was om een markt op te richten. Van de Toba-Bataks is mij zulks niet bekend, maar misschien is dit punt nooit onderzocht.

IX.

De Simbiringstammen.

Mbiring beteekent "zwart zijn», dus si mbiring beteekent «de zwarten». Van de andere stamnamen hebben wij geen juiste vertaling kunnen geven, alleen deze stamnaam geeft ons een woord aan de hand om eenigszins te denken aan een volk van zwarte menschen, zwarter dan de reeds aanwezige bewoners.

$\mathrm{Nu}$ moeten wij al dadelijk beginnen met te zeggen, dat ook deze stam ons geen eenheid toeschijnt te zijn, want al spreekt men van de merga silima "de vijf stammen", toch zagen wij reeds, dat dit meer op een geworden toestand is toe te passen, dan op een oorspronkelijken. Ook bij de Simbirings is wel van het meeste belang de namen van de sub-mergas te bestudeeren, en deze waren het dan ook die den heer Joustra indertijd op het spoor brachten hun herkomst uit Britsch-Indië te verklaren. ${ }^{1}$ )

Al dadelijk valt het op, dat de Bataks zelf dadelijk twee groote groepen in de Simbirings onderscheiden, n.l. de Simbirings die hunne dooden begraven en verbranden en de Simbirings die de asch van hunne dooden laten afdrijven, resp. S. Ke mbaren en de S. Si mombak. De eersten vormen een groote merga met een bepaalde streek (Boven-Langkat en

1) M. Joustra. Doodenfeest der merga Sembiring in Tijdschr. Bat. Gen. dl. 45 (1902) blz. 541 e. v. en dl. 46 (1903) blz. 472 e. v.

Kern. Drawidische volksnamen op Sumatra. Bijdr. Kon. Instit. dl. $5 \tilde{5}$ (1903) blz. 358 e. v.

M. Joustra. Sembiringsche doodenfeest. Bijdr. Kon. Instit. dl. 74 (1918) blz. 618. Zie ook het verslag van het tweede congres van het Oostersch Genootschap, 1922, blz. 42. 
Liang Melas) als woonstreek, de laatsten hebben tal van submergas (Tjolia of Tjoelia, Dēpari, Pelawi, Moeham, Berahmana, Maleala, enz.) en bewonen het rijkje Sarinembah benevens verspreid in dorpen langs het stroomgebied van de Biang-rivier. De uitdrukking "hunne dooden laten afdrijven» moet beperkt worden, tot het volgende. Bij het feest of plechtigheid pekoealoeh geheeten, worden stukjes van de schedelbeenderen van van de in de laatste jaren overledenen, in kookpotten op kleine scheepjes gezet, en laat men alles de rivier afdrijven. Dit is in de ooren der bevolking het groote verschil tusschen de twee Simbiring afdeelingen. Een in het oog loopend groot verschil levert de woonplaats van deze twee deelen der S. op, nl. hunne woonplaatsen. De Kembaren bewonen een zeer groot oppervlak, alles bedekt met oerwoud, waarin verspreid hunne dorpen liggen. Men heeft minstens twee dagreizen noodig om van hun hoofdplaats, Sampē Radja tot aan Bohorok (Langkat) te komen. Maar de S. Simombak wonen verspreid in het land, tusschen de andere stammen in. Hunne voornaamste plaatsen zijn aan de Biangrivier gelegen, die zij stellig gevolgd hebben van het Westen naar het Oosten, nl. Perbesi, Sarinembah, Soesoek, Pajoeng Berastepoe, Kaban Djahē, Siberaja, Adji Djahē en Koeboe Tjoelia. In de Doesoens van Deli en Serdang alleen een klein getal en bijna nergens als dorpshoofd.

Ook de Simbirings geven op uit de Pakpaklanden te komen. Naar de gegevens te oordeelen hebben zij zich van uit het stroomgebied van de Laoe Renoen langs twee wegen naar hun tegenwoordige woonplaatsen bewogen, nl. de S. Kembaren in de richting Laoe Baleng naar Sampe Radja (vandaar gaat nog heden de hoofdweg er heen) èn over het gebergte langs het dorp Kidoepen. Hunne verspreiding naar de Alaslanden (en Gajoe) laten wij hier rusten. Een blik op de kaart toont ons ook hier weer dat deze weg de meest natuurlijke zal zijn geweest.

Ongetwijfeld worden de S. Kembaren door alle stammen als een oude, tot de Bataks behoorende, stam beschouwd. Die van de Boven-Bohorok, geven op dat zij oorspronkelijk S. Keloko geheeten hebben. $\mathrm{Zij}$ kwamen uit Perti, trokken vandaar naar Martogan (dicht bij Lingga Radja in Pakpak??), vandaar naar Koeta mbelin (bij Sampē Radja??) en vandaar naar de Bohorokstreek. 
De naam Kembaran is van later datum, oorspronkelijk heetten zij Keloko. Bij dezen laatsten naam denken wij aan de merga Haloho die in Poerba aan het Tobameer woont. Al die stammen in die streek beweren immers ook uit Pakpak of van Samosir te komen. Keloko (van koko) beteekent in het Karosch "omringd, omheind». Deze stam zou dus "de omringden, de omheinden" geheeten hebben. Kwam dit omdat zij zich door adat of taal van de anderen onderscheidden? Wij denken hier aan het bij de andere Simbirings geoorloofde huwen in den stam. Later heetten zij de Kembaren; Hombar. T. «bij elkaar gelegen, buur»; Kembar. $\mathrm{K}$. "een zijn met, in nauwe verbinding»; Kembarön. GAJ. ook "uithuwelijken» (verwijderen). Uit deze benaming zou men kunnen opmaken, dat zij op een gegeven oogenblik als buurstam zijn beschouwd geworden, in tegenstelling met andere Simbirings. Wij denken weer aan de huwelijksvoorschriften. Hebben zij hun isolement opgegeven en ook den adat ingevoerd dat huwelijk in den stam verboden was, dus zich aangepast aan de andere Batakstammen? Deze veronderstelling ligt voor de hand, want zij onderscheiden zich juist van de andere Simbirings doordat zij geen endogamie kennen en ook huwelijken met andere Simbirings niet geoorloofd geacht worden (met uitzonderingen). Door deze daad zouden zij als Bataks erkend zijn geworden en vandaar hun naam Kembaren, «buurstam». (De Tjoelia en de Dēpari die te Goeroe Kinajan wonen, mogen wel trouwen met Kembarens, om welke reden zal wellicht later duidelijk worden).

Bij het bovenstaande moet opgemerkt worden, dat de Simbirings zich zelven zeker den naam van "zwarten» niet gegeven zullen hebben; wij zullen het ons moeten voorstellen, dat het gegaan is als met de komst der Europeanen. Deze allen noemt men Belanda of orangpoetih, alhoewel zij zich weer onderscheiden in Hollanders, Duitschers, Engelschen enz. Langzamerhand neemt men zelf dien naam over. Zoo zal ook de naam Simbiring gegeven zijn aan al die vreemdelingen die het land binnentrokken. En de tegenwoordige Kembaren zijn dan wel van een ouden "trek». Is onze veronderstelling juist, dat de oorspronkelijke naam Keloko dezelfde is als de Haloho (Poerba)? Y pes vermeldt in Belegen (Pakpak) een Radja Lela, Tiar geheeten, merga Kalako (Kaloko??) en een Panglima, Poesama geheeten van de merga Poerba. Waar moeten wij het dorp Perti zoeken? 
Tot den jongeren trek, en zeker den jongsten moeten wij den trek der Simbiringstammen die zoo verschillende sub-mergas hebben, rekenen. In de sub-mergas (Berahmana, Dēpari enz.) hebben wij een aanwijzing om hun stamland in Engelsch Indië te gaan zoeken. In elk geval wijzen hunne verhalen uit dat zij vanuit het Pakpakland naar het Karoland gekomen zijn. Tideman vermeldt een overlevering waarin gezegd wordt dat Si Singa Mangaradja zijn Atjihsche tjap ontving van een mythisch vorst, radja Oetih, die eertijds in Baros zetelde. Wij vermelden dit hier, omdat Atjih nog naderhand zal ter sprake komen. Wij zullen hier thans niet verder gaan dan aangaande hunne betrekking tot het Karoland. En dan moeten wij aannemen, dat de verschillende sub-mergas niet ineens als een groote golf over het land zijn gekomen, maar dat er telkens kleinere golven elkaar hebben opgevolgd. Dit blijkt als men plaatselijk onderzoekt naar de herkomst van de sub-mergas die hier en daar wonen. Wij komen dan tot de volgende plaatsbepalingen aangaande de sub-mergas.

Van Silahi-lahi (Tobameer) kwamen de Sinoelaki en de Tekang. (deze worden gerekend dicht bij de Kembaren te staan).

» Pandiangan (Pakpak) kwamen de Malēala.

» Poela Berhala? ook de Malēala.

" Paropo (Tobameer) kwamen de Kembaren.

» Sihotang (Toba?) kwamen de Berahmana, Dēpari en Moeham.

" $"$ de Pelawi.

Hoe de Simbirings in het land kwamen, vertelt het bekende verhaal van den Keling die den Sultan van Atjih bedroog door hem een gewitten olifant te laten zien. Toen het bedrog uitkwam vluchtte hij naar het Karoland. Hij vestigde zich in de kampong Keling, welker ligging men niet met zekerheid kan opgeven. Bij het overtrekken van de Riangrivier (Hondsrivier) welke sterk gezwollen was, redde hij zijn leven door zich aan de staart van zijn hond vast te houden en legde de belofte af, wanneer hij veilig aan de overzijde kwam, dat hij, noch zijne nakomelingen, ooit hondenvleesch zouden eten. Hij kwam gelukkig aan de overzijde en ontkwam aldus aan zijne vervolgers. Op bevel van den vorst van Atjih, moest hij gevangen genomen worden en gedood worden, zelfs zijn asch moest in de rivier gestrooid worden. Maar niemand in het Karoland durfde hem aan, want 
hij was rijk en had voldoende wapens. Zij huwden onder elkaar en daarom besloten de Radja Karo te bevelen, dat hunne lijken de rivier moesten afgedreven worden; als men dit niet deed dan zouden de muizen de rijst opeten.

Het merkwaardige in dit verhaal is, dat wij twee redenen vinden waarom de Simbirings hunne dooden laten afdrijven. De eerste is afkomstig van den Sultan van Atjih, omdat de stamvader hem bedrogen heeft, en de tweede is een bevel van de Karovorsten, omdat de door hen gepleegde "bloedschande» (huwelijk met stamgenooten) de rijst zal doen mislukken. Dat bevel van den sultan van Atjih zal wel overeenkomen met het bevel van $\mathrm{ZH}$. aan de Belandas om schoenen te moeten dragen, want hij wilde niet dat hun onreine voeten den Sumatrabodem zouden drukken. Om diezelfde reden behoeven wij ook niet aan te nemen, dat wij hier te doen hebben met een opgejaagden stam. Integendeel, zij waren rijk en voldoende, kan ook luiden: zeer goed van wapens voorzien. $\mathrm{Z}_{\mathrm{ij}}$ hebben als pantangen den hond. Waren het Mohammedanen? Het zal stellig wel dadelijk de andere stammen opgevallen zijn, dat de hond niet gegeten werd.

Dit verhaal betreft de Malèala. Na Keling verlaten te hebben, vestigde zijn zoon zich te Sinaboen (misschien Djinaboen? Thans heerschen daar de Per-angin-angin Soeka tendel).

Vermeldt dit verhaal, dat de Simbiring Maleala als vluchtelingen het land binnenkwamen, het verhaal van de verdwenen Gintingstam Pasē doet zien dat men ze ook het land binnenhaalde. Het is het oude spelletje dat we tot in de jongste tijden zien afgespeeld, dat men buitenlandsche hulp gaat inroepen om zich op zijn tegenstander te wreken. Zoo vermeldt het verhaal van den Sibajak van Koeta Boeloeh hoe hij de hulp inriep van den kedjoeroeen van Batoe mboelan en den Sultan van Deli, om eigen landgenooten te bevechten.

Dit verhaal laat ons den Gintingstam zien, de G. Pase, die door gebrek aan mannelijke opvolgers dreigde uit te sterven. De inhoud moge hier beknopt volgen. - Het tegenwoordige dorp Sarinembah heette vroeger Pasē. Aldaar woonden de Ginting Pasē en G. Soeka. Ginting Pasē (voorgesteld door een eenige dochter) moest wijken voor de G. Soeka. (Weer een bewijs dat de Giriting Soeka stellig de laatste invasie der Gintings geweest is). Nu ging zij hulp halen bij de Simbirings. Deze Simbiring is rijk en kan betaalde voorvechters huren. $\mathrm{Zij}$ komt terug met 
die hulp, slaat alle tegenstanders dood, bevecht zeven doesoendorpen die zich niet onderwerpen willen en het eindigt daarmede dat alle onderhoorige dorpen van het vroegere Pasē den Simbiringvorst erkennen als hun heer. De naam Pasē gaat verloren en heet voortaan het dorp Ari si nembah of Sarinembah. Het eenige meisje van den G. Pasê-stam is gehuwd met den Simbiringvorst. Thans is deze vorst ook een radja berempat, heeft dus een zeer belangrijke plaats in het Karoland ingenomen. Maar de Ginting Soeka hebben een zeer belangrijk stuk van hun gebied aan deze Simbiring moeten afstaan.

Ook hier weer is het een S. Malēala, evenals in het reeds genoemde verhaal. Voor de geschiedenis is het van belang op te merken, dat de K. K. Sinoe Raja reeds in het land waren, zij waren de anak-beroe-menteri van de Ginting Pasē. De anakberoe van de G. Soeka waren K. K. si noe Kaban. Wij weten reeds dat de Rajasche K. K. te Singamanik woonden (vlak naast Sarinembah gelegen) en dat hun invasie ongeveer 150 jaar geleden moet hebben plaats gehad. Als daarna pas de Simbiring Malēala Sarinembah hebben ingenomen en de Gintings Basē hebben uitgeroeid, dan moet dit na dien tijd geschied zijn.

De namen van plaatsen in dit verhaal vermeld geven weinig licht. De S. die met het Pasē-meisje trouwt, is een zoon van den pengoeloe van Djandi Melasang, welk dorp niet thuis te brengen is. Tenzij elders dan in het Karoland. En het mythische Berhala, waar de geesten-vorst-toovenaar Datoe Roebia gande ${ }^{1}$ ) woont, zullen we maar voor versiering van het verhaal houden. Wij kunnen alleen zeggen, dat de Malēala vermoedelijk reeds ergens zich gevestigd hadden, en door de Pasē te hulp geroepen, zich voorgoed in het Gintinggebied vestigden.

Een oogenblik moeten wij nog stilstaan bij den naam Sarinembah; op het eerste gezicht zouden we dezen naam willen ontleden als Sari en nembah; sari is een oud voorvoegsel, dat alleen nog in eigennamen voorkomt. Maar het verhaal meldt, dat het eigenlijk Ari si nembah moet zijn. Wij hebben nog zulk een dorpsnaam, nl, Adji si nembah of kortweg Adjinembah. In beide namen zit een woord dat in het oud-Javaansch "vorst» moet

1) Uit het verhaal van de Radja Bajan zou men kunnen vermoeden. dat de woonplaats van dien god-toovenaar op het Boeaten-gebergte lag, in de buurt van Lajo-Lingga. 
beteekenen. ${ }^{2}$ ) Ari en Adji. Op dit oogenblik is a ri niet meer bekend in het Karosch en adji alleen als een soort tooverpreparaat, dat vooral ongeneeslijke wonden veroorzaakt. Verder is er ook nog een sub-merga van de Simbiring die zich boenoea dji noemt, wat ik naar analogie van Boenoeraja wel verklaren wilde als Banoea Adji, het land der Adjis. Ari en Adji si nembah zou dan beteekenen "de vorst die zich onderwerpt». Waar zullen we dit "land der Adjis» moeten zoeken? Het zij allen aanbevolen dit te onderzoeken, wellicht geeft dit weer een draad in handen. Het dorp Adjinembah, vlak bij den berg Kosar gelegen, is in handen van den G. stam en is later onderworpen door de G. Soeka. (Zie wat er gezegd is van den Gintingstam aldaar).

Dat de Simbiringstam jonger is dan de andere stammen zien we ook uit de verhalen betreffende de stranddorpen Paropo en Silahi-lahi. Beide dorpen moeten vroeger in handen zijn geweest van den Gintingstam, nl. de Moentē. Maar thans heerschen daar de S. Kembaren in Paropo en in Silahi-lahi heerschen de Simbiring Pajoeng, Depari en Pandia. We vragen alweer: staat Pandia in verband met Pandiangen (Pakpak)? Pandiangen wordt in het Karosch Pandiān en het volk zal dit dan aangezien hebben voor pandia en an.

In de Pakpaklanden vindt men ook een merga Oedjoeng Pajoeng en Pajoeng, ze wonen in de rijkjes Binang en Longkip. Indien dat dezelfde zijn als die van de andere stammen, nl. van de Pakpaklanden naar het Oosten, steeds volgende de Singkelrivier en zijn bijrivieren.

Nog enkele kortere noties mogen hier een plaats vinden. De S. Dēpari, S. Moeham en de S. Berahmana wonen ook in het dorp Perbesi. Zij kwamen wat de eerste twee betreft uit Siberaja en wat de laatste betreft uit Kaban Djahē. In Perbesi hooren wij ook dat deze S. afkomstig zijn van Sihotang (Toba). Daar kwamen ook Karo-karos vandaan, maar de Karo-karos waren daar eigenaars van den grond en de Simbiring slechts ginemgen. In Sihotang waren dus de Simbiring ook later gekomen dan de daar wonende Karo-karos.

In een verhaal over den Goeroe na bolon, wordt zonder zijn

2) Het O.-Jav. woord, dat de schrijver bedoelt, is haji (Juynboll, Oudjav. Ned.-woordenlijst, p. 650). [Redactie]. 
stamnaam te noemen van den grooten goeroe gezegd dat hij afkomstig was uit het dorp Peling-pelingen in Pakpak.

Nog een andere wijze waarop de Simbirings een plaats kregen in het Karoland vinden wij in een verhaal aangaande Soeka tepoe. Dit dorp, gelegen in een streek waar alieen Karo-karo grondeigenaars zijn, behoort aan den S.stam. Dit eigenaardige geval wordt op de volgende wijze verklaard. De pengoeloe van Deskati had geen kinderen. Nu kwam er een Simbiring Boenoe Adji welke hem behandelde, met dit gevolg dat hij een zoon kreeg. Uit dankbaarheid voor zijn genezing schonk de pengoeloe van Deskati aan den Simbiring Boenoe Adji een stuk land in eigendom en zocht ook een vrouw voor hem. Daarom hebben de Simbirings het dorp Soeka tepoe en zijn ook eigenaars van den grond.

Dit verhaal, dat ons alleszins geloofwaardig voorkomt, gezien dat men bij kinderloosheid alles doet om een zoon te krijgen, laat ons weer een weg zien hoe de S. in het land kwamen. Ook waar elders S. anak-beroe of kalimboeboe zijn van de hoofden die daar regeeren, is de reden meestal het huwelijk met een S. meisje of omgekeerd geweest. Het met elkaar huwen zal dan ook wel de oorzaak zijn geweest dat deze stam tot de vijf stammen gerekend geworden is, tenzij reeds in Pakpak de Simbirings verwant waren met de andere stammen, wat men wel zou vermoeden uit het medegedeelde van Perbesi.

De raadselachtige figuur van den telkens in de verhalen genoemde goeroe Pakpak pitoe si dalanen, is in een der verhalen een Simbiring. Hij verbindt met zijn toover- en medicijnkunst ook het smeden van goud en zilver. Om zich heen verzamelt hij leerlingen en is in hunne oogen de leermeester. De smeedkunst geeft hij op, want het goud wil niet meer smelten en het ijzer wil niet meer gloeiend worden. Nu gaat hij er op uit met zijn perminakan si badak na bolon (oliepotje, denkelijk met een stop gesloten waarop een neushoorn afgebeeld is), zijn toengkat malëkat (tooverstaf met een ruiterbeeld als knop), en zijn poestaka na djati (echte of oorspronkelijke tooverboeken). Deze drie dingen zijn in de verhalen drie attributen. Zijn metgezellen zijn van een anderen stam, zooals wij zien in het verhaal van Singa waar een peranginangin zijn metgezel is. Merkwaardig is, dat de tooverkracht van zijn perminakan overwonnen wordt door die van een Simbi- 
ringmeisje, dat haar oliepotje uit den mond van een Begandingslang heeft gehaald en waarmede ze zelfs een maaltijd kan te voorschijn tooveren. Let wel, dat het ook weer een Simbiringmeisje is, dat in het bezit gekomen is van een perminakan.

Alhoewel we niet te veel kunnen bouwen op zulk een verhaal moeten we toch enkele dingen naar voren brengen, mede in verband met wat we elders opmerkten. De tooverkunsten die men uithaalt met de perminakan en de toengkat malēkat worden hier aan een Simbiring toegeschreven. Deze is bovendien leermeester in goud-, zilver- en ijzerbewerking. Hij bezit ook de poestaka na djati, die, in een door mij gehoord verhaal, van goud moet zijn geweest en in het bezit was van den god der middenwereld Toean Banoea Koling, "de Heer van het Klingenland». - Nog een andere opmerking betreft den tooverstaf. Er zijn er namelijk twee, de tongkat malēkat, een gewone stok die als knop een ruiterbeeld (een enkele maal een olifantsbeeld) heeft, en de tongkat penaloean, die geheel besneden is en het verhaal van Si Donda ketakoetan moet voorstellen. Nu brengt men wel de t.malēkat met den Goeroe Pakpak in verbinding, maar niet de t.penaloean. Daar mij geen verhaal bekend is aangaande den t.malēkat (ook van den Sultan van Atjih zegt men dat hij als stok de tongkat malekkat gebruikt), laat ik verder dit vraagstuk rusten, maar breng het toch onder de aandacht van allen die mogelijk zulk een verhaal bezitten.

In een verhaal dat in verband gebracht wordt met het graf van de Gajosche of Atjihsche voorvechters, dat dicht bij Lingga aan de Lahoe Rahoem ligt, komen enkele merkwaardige gezegden voor, die ik hier naar voren zal brengen, ofschoon het verhaal zelf allerlei dingen door elkaar haspelt. Allereerst wordt daar gezegd, dat de Simbirings de armsten waren onder de vijf stammen, want ze hadden weinig bouwgrond en weinig bosch. Maar onder hen waren vele slimmerikken. De verteller brengt dit in verband met hun kennis om onkwetsbaar te maken, ziekten te verwekken, en meer tooverijen. Verder vertelt hij, dat de Sultans van Atjih hun anak-beroe Perasi noemen en hen als zendelingen gebruiken tot in het Batakland toe.

Dan springt hij over op het bekende verhaal van den gewitten olifant, maar op een geheel andere wijze dan reeds vermeld is. De Simbirings besloten den Sultan van Atjih te bedriegen. Ze namen een grooten buffel en zes zakken met rijstemeel. Toen 
voeren ze over het Tobameer naar Atjih. Daar gekomen, maakten zij den buffel geheel wit met rijstewatermeel en boden hem den Sultan van Atjih aan, onder den naam van "witte olifant». De Sultan was er mede in zijn schik en gaf hun eenige duizende guldens. Spoedig daarop vertrokken zij. Toen het bedrog ontdekt werd, liet de Sultan ze achterna jagen en men doodde er velen. Enkelen bleven echter leven, ze zwommen naar het land, waarbij zij zich aan de staarten van hunne honden vasthielden. Het verkregen geld verdween in het Tobameer en wegens de redding door de honden eten ze ook geen hondenvleesch.

$\mathrm{Nu}$ moesten de $\mathrm{S}$. rijstvelden gaan aanleggen, maar de rijst droeg geen vrucht. Daarop plantten zij tjingkeroe en die droeg heel veel vrucht. De vruchten werden door hen opgeborgen in een rijstschuur. $\mathrm{Nu}$ gebeurde het eens dat er onopgemerkt een kind in de tjingkeroe viel. Daar de vruchten zeer glad zijn, zonk het kind er in weg, en stikte er in. Later vond men het lijk en begroef het, maar voortaan plantte men geen tjingkeroe meer. (In een ander verhaal is dit laatste gebeurd met een kind van de Tarigan Selangit, daarom planten de T. Selangit geen tjingkeroe meer).

De verhaler verbindt nu de komst van Perasi naar het Karoland aan het bedrog met dien buffel. Door hem beval de Sultan dat de S. voortaan niet begraven mochten worden, maar de asch van hun lijk moest men de rivier laten afdrijven.

Weer later zond de Sultan van Atjih drie zendelingen met de boodschap: Wat willen jullie liever: beheerscht worden door Simbiring dilah (de zwarttong) of door de si mbentar mata (wit-oogen)? De Bataks zeiden: door de wit-oogen (Europeanen). Toen zeiden die zendelingen: Dan wil Atjih jullui ook niet beheerschen - en gingen heen. Maar ze werden weggejaagd en een er van werd gedood terwijl hij sliep. Deze ligt te Laoe Rahoem begraven.

Het laatste stuk van het verhaal is nog van historischen tijd, want indien ik mij niet bedrieg, heeft de overleden Pa Melgah dien Gajoeschen panglima gedood. Maar dit daargelaten, ons treft den naam Perasi. De Bataksche verklaring van dit woord is Peratjih «de Atjih-man». Deze verklaring is mogelijk indien het via een Tobasch dialect in het Karosch gekomen is, immers de Toba-Bataks kunnen de $\mathrm{tj}$ niet uitspreken en maken er een s van. Maar het is thans nog een titel, dien de pengoeloe van 
het dorpje Penoengkiren in de Doesoen van Deli draagt. Deze Perasi heeft krachtens zijn titel zitting in de rechtbank van de Boven-Doesoen van Deli en hij wordt beschouwd als de anak-beroe van de oeroeng XII koeta. Mij is niet bekend of er meer menschen bestaan met dien titel in het Karoland. Volgens ons verhaal was hij dus een zendeling van den Sultan van Atjih. Perasi staat dus naast Atjih en tegenover den Simbiringstam.

De vraag is nu echter of het niet een rudiment van een oude wijze van stambestuur geweest is. Ypes vermeldt dat in de Pakpaklanden een officieel aangesteld man, permangmang geheeten, als stamwichelaar voor het landbouwbedrijf dienst deed en tot de officieele personen in een dorp behoorde. Mangmang beteekent in het Karosch «formule», zooals de formule bij het afleggen van den eed, bij tooverijen enz. Hij is dus de man die de formules kent. Daarom ligt het voor de hand ook hier aan zoo iets te denken. In het Karosch kent men ook het woord rasi "lot, gesternte», ngogē rasin «iemands lot onderzoeken», la serasi «ergens niet gelukkig zijn». Mogelijk dat perasi de rol vervuld heeft van den permangmang en vroeger de officieele priester van den stam geweest is.

Een tweede opmerking geldt het vermelde over de armoede van de Simbirings, uit gebrek aan grond en bosch. Dit lijkt mij wel aannemelijk voor een vreemden binnengedrongen stam. Hier en daar zal dit ook wel het geval zijn geweest. We zagen immers reeds, dat men ook de Simbirings niet behoeft te beschouwen als een eenheid, maar dat de verschillende verhalen wel degelijk onderscheid maken tusschen de verschillende sub-mergas der Simbirings. Het is best mogelijk dat ze hier en daar zich genesteld hebben als bijwoners en eerst later, toen zij zich sterker voelden, met kracht van wapenen zich eigendomsrechten verworven hebben. De opmerking dat ze slim en knap waren in allerlei kunsten en tooverijen stemt wel overeen met de verhalen van den goeroe Pakpak pitoe si dalanen. Het waren dan eerst reizende toovenaars, smeden, enz. die van hun beroep moesten leven. Levende in het Pakpakland kwamen ze eerst af en toe naar het Karoland en door hun hoogere cultuur hadden zij een zeker overwicht over het Karo- en Gintingvolk. Of het verhaal van het planten van tjingkeroe eenige waarde heeft, daar ditzelfde ook van den Tariganstam verhaald wordt, laat ik rusten uit gebrek aan meer- 
dere gegevens. Het kan zijn dat zij de tjingkeroe het eerst in het land geplant hebben.

Heel opmerkelijk is echter de hier vermelde tocht naar Atjih. Men vaart met een buffel over het Tobameer naar Atjih. En in plaats van de tocht over de Biangrivier aan de staart van een hond, staat hier het overzwemmen van het Tobameer op hun vlucht voor de Atjihers. Atjih was dus via het Tobameer te bereiken. Brengt men dit in verband met de boodschap van den Sultan van Atjih: door wie wilt gij overheerscht worden, door de "zwarte tong», of .... dan denken wij onwillekeurig aan $\mathrm{Si}$ Singamaharadja. Van hem werd immers beweerd dat hij een zwarte tong had en zijn woonplaats was bij Bakara bij het Tobameer. Was dus de Singamaharadja dezelfde als de Sultan van Atjih?

Het is best mogelijk dat dit het geval was. De Karo-Bataks hebben dan nimmer rechtstreeks te doen gehad met Atjih, maar met den Singamaharadja. Wat Tideman (pag. 36) zegt: "alle gegevens... wijzen er op, dat deze vier vorsten als zoodanig de vertegenwoordigers van $\mathrm{Si}$ Singamaharadja, den bekenden priestervorst der Bataks, waren», geldt dan ook van het Karoland. De instelling van de radja berempat in het Karoland is dan terug te brengen tot dezen priestervorst en dat is dan veel meer en beter te begrijpen dan dat dit vanuit Atjih zelf zou hebben plaats gehad. Het Pakpakland is beter te bereiken vanuit de Karo-hoogvlakte dan Atjih. Indien de volksetymologie van den titel Perasi als zendeling van Atjih juist is, dan zouden het zendelingen van Singamangaradja geweest zijn.

Of de Simbiringstam in eenig verband te brengen zou zijn met de heerschappij van Singamangaradja blijkt uit niets. Integendeel blijkt, dat Atjih den Simbirings vijandig gezind was. Zij zijn dan waarschijnlijk langs de Singkelrivier het land binnengekomen toen de macht van Singamangaradja reeds gevestigd was en geen welkome immigranten geweest. Vandaar dat zij in de richting van het Karoland verdrongen zijn geworden.

$\mathrm{X}$.

De Perangin-anginstam.

De afkomst der Perangin-anginstammen is ook in de verhalen aangewezen als zijnde uit de streek van de Laoe Renoen. Het dal dat thans bekend staat als de streek van Simbetek herbergt 
nog Perangin-anginstammen. De dorpen Pinem en Laksa worden genoemd als de kampongs vanwaar de meesten naar de Goenoenggoenoeng getrokken zijn. Een stam, de P. Bangoen moeten afkomstig zijn van Sigala (in Toba??): zij trokken eerst naar Siantar en vandaar naar de G. goenoeng, waar zij het dorp Bangoen moelia stichtten. Een ramp, volgens de beschrijving in het verhaal een aardbeving, deed het dorp ineenstorten en toen verspreidden zij zich en stichtten de dorpen Batoekarang Penampen, njandi Meriah, Nare Goenoeng, Tandjoeng, Pajoeng, en Koeta Galoeh. Zij vormen de oeroeng Si lima senina, «de vijf broeders». Dit is dus een trek geweest van het Oosten naar het Westen. Ypes vermeldt de merga Segala in de Pakpaklanden in Pasir belo.

Toch zijn de Bangoen in Bangoen moelia niet de eerste P. geweest, zij moeten daar al de P. Mano gevonden hebben, waarvan er nog een enkele familie moet leven.

De Perangin-angin, welke in Djoehar wonen, geven ook op afkomstig te zijn van Laksa, en de Pinem komen van het dorp Pinem. Dit laatste dorp moet vroeger onder de macht van Liren gestaan hebben.

Een stam van de P., de Sibajang, schijnt ook een groote rol gespeeld te hebben. $\mathrm{Zij}$ bewonen thans de dorpen Koeala, Goenoeng en Koeta Gerat. Ook hebben zij zich naar de Alaslanden uitgebreid en moeten in Oea Namboek wonen. Als de plaats waar zij vandaan komen noemen zij het dorp Toeha in Pakpak. (Ik heb op geen der beschikbare kaarten deze plaats kunnen vinden). Vandaar kwamen zij in Perbesi, waar toen de P. Pintjawan heerschten. Het verhaal meldt dat het een speler was die daar aankwam. Door een ongeluk doodde hij de vrouw van den vorst en kwam zoo in het blok. Dit heet Bajangen, en van daar dat zijne nakomelingen $\mathrm{P}$. Sibajang heeten. Na, door zijn goed gedrag uit het blok losgemaakt te zijn geworden, huwde hij, en zijne nakomelingen waren zoo talrijk, dat zij eindelijk de P. Pintjawan wegjoegen en zelf heerschers in Perbesih werden. De P. Pintjawan of Pentjawan trokken naar Laoe Banban ten zuiden van Temboeroën. De Sibajangs maakten daarop een djamboer waaronder negen palen, onder elken paal een menschenhoofd. Die hoofden werden genomen (geroofd) uit Sarinembah, Koeta boeloeh, Djoehar en Lingga. Men kan ook zeggen dat die dorpen ze leverden, waartoe zeker slaven het leven lieten. Deze djamboer is tot heden toe nog de vereenigingsplaats van deze merga. De invasie der Sibajangs 
schijnt dus nog van jongen datum te zijn, daar reeds de dorpen die de hoofden leverden, bestonden.

In het algemeen kan men zeggen dat de P. meer naar het Westen getrokken zijn en de streek van Koetaboeloeh, Laoe Baleng enz. bevolkt hebben. De naam Perangin-angin, door M. Joustra vertaald met * windhoekers», geeft niet veel houvast om eenige conclusie uit te trekken. Ik weet ook geen andere vertaling te geven.

Van de andere P. zijn ook nog te noemen de P. Soeka tendel, af komstig van het dorp van dien naam en heerschende in Koeta Boeloeh. De P. noemen die streek daar Namoe adji of Namoe Hadji. Zij onderscheiden zich in de P. Pengoeloe en de P. Sibajak. (Dezelfde onderscheiding vindt men bij de K.K. sinoe Lingga.) De eerste zijn afkomstig van Siantar (Oostkust), de laatste van het dorp aan het Tobameer Silahi-lahi. Als uitwendig kenmerk hebben de Sibajak-stam-leden de oorlellen doorboord. Dit is een (algemeen?) gebruik op het eiland Samosir. De van Siantar komenden kennen dit niet. Ook is zeer opvallend dat de P. Sibajang en de P. Koetaboeloeh met elkaar huwen mogen. Ook is het aan deze stammen verboden witte (roode) buffels te eten.

Volgens hunne opgaven hebben de P. Koetaboeloeh indertijd van Siantar tot bij Bindjei (Bingei) gewoond. $\mathrm{Zij}$ waren als helden bekend, daar zij oorspronkelijk in Bingei de wangkah(?) gedood hebben. Dit moet een soort wild zwijn geweest zijn, dat menschen at. Een P. doodde het beest door in een boom te klimmen (een kajoe hadji of adji). Deze boom stond in een moeras waar de wangkah leefde en zich dagelijks aan dien boom schuurde. Naar dien boom hebben zij voortaan hun district genoemd Namoe adji.

Het bestaan van twee soorten P. naast elkaar, doet weer denken aan een overheersching, de voorname stam zijn de Sibajaks, de "rijken", de overwonnen stam zijn de pengoeloe, de dorpshoofden. Heel lang kan deze invasie nog niet geleden zijn, gezien het feit dat de Sibajak van Koeala ook een Perangin-angin is, en een oude inwoner van Perbesi wist nog dat dit dorp opgericht werd.

Een andere submerga is de P. si noe oerat. Het verhaal gaat, dat de stichter van deze merga een uitgestootene was, en zich vestigde in Kerenda. Deze eten wel den witten buffel.

Een andere submerga is de P. Katjinamboen, die mij op- 
gegeven werd als wel de oudste submerga te zijn, daar men haar beschouwd als aan alle $P$. verwant.

\section{XII.}

De Tariganstammen.

De Tariganstammen bewonen de si $\mathrm{V}$ koeta en Nagasariboe en eenige dorpen tusschen de Gintings en Perangin-angins in de streek bij Djoehar, nl. de dorpen Keriahen, Betoeng, Koetambelin, Pergendangen, Koeta Galoeh en Djoehar.

Deze twee uit elkaar liggende streken wijzen, gesteund door de verhalen, op een tweetal wegen gevolgd op hun verhuizing naar de Karolanden. Ook hier blijkt het belang van de namen der submergas, daar zij ons een en ander kunnen laten zien.

De naam Tarigan is nog onverklaarbaar; men kan vermoeden dat het grondwoord tigan moet zijn, daar men af en toe den naam Tigan of Tigen aantreft, welken men niet verklaren kan.

De radjageslachten in Tjingkes en Bawang zijn T. Tambak en T. Gerneng, in Nagasariboe zijn het T. Gersang en Tambak. Deze landstreek sluit zich aan bij het gebied van Dolok en in Dolok Silau regeeren de T. Tambak. Tevens grenst dit gebied aan het rijkje Poerba, waar ook Tarigans wonen, nl. de merga Poerba, die volgens opgave van Tideman als sub-mergas hebben: Gersang, Tambak en Bawang, welke in het Karogebied als Tarigans gelden. De merga Poerba moeten we dus tot de Tarigans rekenen. In Poerba wordt ook een $\mathrm{P}$ oerba $\mathrm{Pakpak}$ genoemd, tot welke merga de Toehan Poerba behoort. Dit Poerba moet gelegen hebben ergens in de Pakpaklanden. (Zie het vermelde van de K. K. Poerba). Daar er in Poerba ook een merga P. Tondang bestaat, denken wij dadelijk aan de opgave van Ypes, die in zijn Nota verhaalt: *Vroeger moeten aan de Tjinendang drie rijkjes gelegen hebben, Sabeak ${ }^{1}$ ) geheeten, nl. I. van de merga Angkat, II. van de merga Tendang, hoofdplaats Panisihan, bij Pakiraman, III. van de merga Boeala ara. Deze zijn later verdwenen.»

Hebben wij in Poerba de verdwenen merga Tendang weder? Dan bevestigt dit weer ons gevoelen voor alle stammen, dat de trek van West naar Oost is gegaan. Dit wordt bevestigd door

1) Sabeak stellig het Kar. Simbiwak of Semboejak "van een ingewand; van een vader." 
de verhalen der Tarigans bij Djoehar, die alle vertellen dat de plaats van herkomst Toengtoe batoe geweest is. Een enkel dorp uitgezonderd, nl. Pergendangen, dat van Nagasariboe uit bevolkt is geworden.

Een belangrijke rol hebben de Tarigans niet in het Karoland gespeeld, behalve dan het verband dat er zijn moet tusschen dezen stam en de KK. Poerka. Wel komt de submerga Tjibero of Sibero ook voor in de Pakpaklanden in het rijkje Binang.

Heeft de Baroesstam zijn held Groot-oor, de Tariganstam heeft zijn held ook. Er zijn verhalen in omloop van een held van den stam Tarigan Kerandam toea. Zijn naam luidt in de verschillende verhalen si Noean kata, si Onan katana, si Nongon kata, si Ngenan kata. Welke de ware is valt niet uit te maken. Moederzijds was hij van de Katarenstam. Hij was afkomstig van Koeala (denkelijk in de Goenoeng-goenoeng gelegen). Door een oom uit Balesisi of Banoea sini bedreigd, vlucht hij en komt terecht bij een oom van hem in Padang Sambo. Hier trouwt hij met zijn nicht. Na een jaar gaat hij naar Soego en trouwt daar weer. Zijn vorige vrouw wil zich op hem wreken wegens zijn ontrouw en beoorloogt Soego. Weer moet hij vluchten en gaat naar Deli. Daar sticht hij het dorp Ale Deli. Na twee jaar vaart hij naar Sait en verovert die plaats. Hij verandert den naam in Siak.

Later zond hij een brief en een mes aan den Sibajak Sipoet. Misschien is dit Soengei Sipoet of Laoe Tjih, gelegen bij de tegenwoordige onderneming Bekalla in Deli. Deze Sibajak moet een voorvader zijn van den vroegeren Sibajak Pa Pelita van Kaban Djahe. Deze laatste was een K. K. Poerba, een Tarigan eigenlijk, als deze Poerbas van het rijkje Poerba afkomstig zijn. Er zou dus verband bestaan tusschen Tarigan en Siak. Ik meen mij te herinneren dat de Sibajak Pa Pelita ook beweerde familie te zijn van den Sultan van Siak.

Siak speelt ook een rol in een der redacties van het verhaal van si Poetri Idjo. Hier laat men de prinses geboren worden in de kampong Goenoeng Lintang (boven de onderneming Rimboen in Deli), gelegen langs de rivier Laoe Toetoengen. Op de oeroek Langkah had zij zich verschanst en daar de Sultan haar hebben wilde voer hij de Toentoengenrivier op om haar te halen.

Ook in Bindjei bij Batoe Merah moet een soort zand- of 
aschveld liggen dat men met onzen held in verband brengt, nl. met si Noean kata.

De Tarigans van Nagasariboe noemen het dorp Lehoe als plaats van de herkomst van hun tegenwoordig radjageslacht. Dus ook weer Pakpak. Een Tarigan Sahing was nl. op de jacht verdwaald geraakt en kwam in de buurt van een dorp Naga terecht (er bestaat thans nog een dorpje Naga dicht bij Lajo Lingga). Daar het hem gelukte de vorstin te genezen en daar deze geen zoons had, huwde hij haar dochter en werd zoo hoofd van het dorp. De titel is daar Toehan en wijst dus heen naar Simeloengoen.

Deze Toehan behooren tot de Tarigan Sahing, welke naam ook weer wijst op twisten en strijd. Later scheidden zij zich in de T.Sahing die het handwerk van hun voorvader voortzetten, nl. de jacht, en de T. Idjoek, die zich op palmwijntappen en misschien ook wel op sagokloppen toelegden.

\section{XIII}

Samenvatting.

Wanneer wij onze aanteekeningen uit de verschillende verhalen samenvatten, dan kunnen wij, behoudens latere ontdekkingen, thans tot het volgende beeld komen.

Op de Karohoogvlakte heeft in een niet nader te bepalen tijd een stam gewoond, die zich de Karo noemden (Tobasch Haro). Dit moet een belangrijke stam geweest zijn, waarvan een tak ook naar Samosir en naar Asahan is gegaan. Hoever echter het gebied van dien stam zich heeft uitgestrekt laat zich met onze gegevens niet bepalen. Thans is er nog een kleine rest overgebleven in het dorp Siberaja, welke zich ter onderscheiding van het mengelmoes van andere stammen die later binnengetrokken zijn, de Karo sekali noemt.

In dit Karogebied hebben invasies van verschillende andere stammen plaats gehad, allen $\min$ of meer verwant aan deze Karo. Volgens hunne stamverhalen zijn ze zonder uitzondering afkomstig van de Pakpaklanden. Deze stammen heeten Raja, Poerba, Baroes, Lingga en Sitepoe. Allen werden door de Karo sekali of door andere stammen niet voor echte Karo aangezien en noemden zich daarom Karo-karo "de op de Karo gelijkende, 
of de on-eigenlijke Karo». Deze invasies hebben 250 of 300 jaar geleden een aanvang genomen. $\mathrm{Zij}$ restigden zich tot in de laagvlakte bij Deli Toea en Bindjei.

De Tarigan kwamen van Dolok en Simeloengoen het land in, maar ook van Lēhoe uit het Pakpakgebied, en trokken naar Nagasariboe en Djoehar. Een Tarigan moet in de benedenlanden Alē, Deli(?) gesticht hebben en zelfs tot in Siak invloed geoefend hebben.

De Gintings kwamen over Tengging en over het gebergte (Lajo Lingga) het land binnen. De tijd valt niet te bepalen, maar vermoedelijk eerder dan de andere Karo-karostammen. Ploeg en buffel hebben zij waarschijnlijk mede gebracht. Hun gebied moet belangrijk geweest zijn, de Simbirings hebben hen een heel stuk afgenomen.

De Perangin-angin volgden den weg Pinem, Lajo Lingga. $\mathrm{Zij}$ trokken noordwaarts naar Koeta boeloeh en de westzijde van den Sinaboen. Ook trokken zij het gebergte over naar de laagvlakte tot bij Bindjei. Alleen de P. Batoekarang zijn van Siantar gekomen, maar geven toch op van de Pakpaklanden te komen.

De Simbirimg Kembaren volgden den weg naar Laoe Baleng en over Sampēradja (Liang Melas) naar Bohorok in Langkat. Verder ook naar de Alasstreek.

De jongste invasie is die der andere Simbiringstammen (Berahmana, Malēala, Dēpari enz.) welke denzelfden weg genomen hebben, maar oostwaarts de Biangrivier stroomop gevolgd hebben naar Siberaja. Heel lang geleden kan dit nog niet geweest zijn, zooals we zagen uit het verhaal van Perbesi, misschien 100 tot 150 jaar.

Alles wijst dus voor de tegenwoordige bevolking op een herkomst van uit het stroomgebied van de Singkelrivier of andere rivieren aan de Westkust van Sumatra. Alleen heb ik geen spoor van de Karo Sekali, de echte Karo kunnen vinden in de mij bekende gegevens uit de Pakpaklanden. Waar deze van afkomstig zijn is mij volkomen duister.

Onwillekeurig komt de vraag op: wat bewoog deze stammen hun woonplaatsen te verlaten? Dit moet volgens de ons ten dienste staande gegevens zooals hier boven bleek omstreeks het jaar 1600 of 1650 geweest zijn. Wij wagen het hier enkele veronderstellingen uit te spreken, op grond van vermoedens gerezen bij het lezen van de stamverhalen.

Dl 82 . 
Ook op de Westkust is de Hindoe-invloed gebleken. Als niet deskundige wijs ik met bescheidenheid op het vinden van een steen met Tamil-opschrift in het gebied van de Singkelrivier (de inhoud van dit schrift is mij onbekend) en verder op den Hindoe-invloed in het Menangkabausche. En uit de verhalen moeten de Simbirings in de Pakpaklanden gewoond hebben en vandaar uit naar het Tobameer (Silahi-lahi en Paropo) en de Karolanden getrokken zijn. Het is mogelijk dat deze Tamil-invasie de aldaar wonende stammen bewogen heeft dieper het binnenland in te trekken. Of dit gewelddadig heeft plaats gehad kunnen we niet zeggen. In het Karoland zien wij ze met geweld en met andere middelen, vooral aanhuwelijking, vasten voet krijgen. $\mathrm{Zij}$ maken nu eens den indruk van rijk en goed van wapens voorzien te zijn, dan weer zijn ze zwervende priesters en handwerkslieden, dan weer arm en toovenaars.

Belangrijk echter is het reeds genoemde verhaal dat zegt dat Atjih aan het Tobameer lag. Als "Zwarttong» (de Singamangaradja) voor den Radja Atjih is aangezien, dan wordt veel duidelijk dat over Atjih handelt. Dan zou er een strijd zijn geweest tusschen Atjih en de Simbirings, waarbij de Simbirings het hebben afgelegd en gevlucht zijn. Deze strijd werd dan gevoerd aan de Westkust, waarbij Singamangaradja de partij van Atjih vertegenwoordigde. Deze zou dan ook uit naam van Atjih de viervorsten (radja berempat) aangesteld hebben, zoo dat de bewering dat Atjih deze vorsten benoemd had langs een omweg toch waar zou zijn. Een bezwaar is er tegen deze stelling, nl. een van de viervorsten is een Simbiringvorst (Sarinembah). Dit is werkelijk een bezwaar, tenzij latere politiek medebracht om oude veeten te vergeten. 
Toevallig hoorde ik eenigen tijd geleden den naam Nagoer noemen. Natuurlijk dat ik dadelijk aan het rijk Nagoer dacht dat indertijd op de Oostkust van Sumatra gelegen moet hebben. Zie Tideman, Simeloengoen, pag. 33 vvlg. Bij navraag hoorde ik het volgende verhaal.

«Het stuk land, dat Nagoer heet, ligt tusschen Singamanik en Bintang Meriah (Goenoeng-goenoeng van de Karo-Hoogvlakte), aan de Biang (Wampoe)-rivier. Het dorp is thans verdwenen, alleen het stuk grond noemt men nog Nagoer.

Het daar gebeurde luidt als volgt: "Die in het dorp regeerde was iemand van de Perangin-angin-Mano-stam. Het dorp was niet zwaar bevolkt. Het dorpshoofd kende de dertig dagen (was een heidensche priester dus, die de goede en kwade dagen wist). $\mathrm{Nu}$ heette een van de dorpsbewoners Matēboelan (doode of nieuwe maan). En dat is ook een van de namen der acht en twintig dagen van de maand.

Toen nu een kind van Matēboelan geboren werd, ging hij dadelijk naar het dorpshoofd, die aan de badplaats bezig was zich te baden, om hem te vragen op welken dag zijn kind geboren was. Hij zeide: "Wat voor een dag is het vandaag?" - Toen zeide het dorpshoofd: «Matēboelan». - De vrager schrok (want hij hoorde zijn eigen naam). Hij vroeg hem opnieuw en kreeg hetzelfde antwoord. Nu meende hij, dat het dorpshoofd hem wilde beleedigen. Daarom beleedigde hij hem terug met te zeggen: "Matē Mano, koega?» (zinspeling op Matēboelan: ongeveer te vertalen met: Hoe, als ik zeg Matē Mano? Hij noemt dus den stamnaam van het dorpshoofd).

Omdat hij aldus tot het dorpshoofd sprak, werd deze boos, ze kregen ruzie en hakten op elkaar in tot ze beiden dood waren. Daarom heet deze bron nog altijd de "bloedbron, omdat het bloed van deze beiden daar gevloeid heeft.

$\mathrm{Na}$ den dood van het dorpshoofd, verhuisden de bewoners 
van Nagoer overal heen, omdat hun dorpshoofd uitgeroeid was (weggevaagd, hij scheen dus geen kinderen te hebben; of: de geheele Manostam was weggevaagd).

De Manostam is thans uit het Karo-Batakland verdwenen.»

Tot zoover mijn berichtgever.

Dit verhaal is daarom merkwaardig, omdat het een aanduiding kan zijn dat het rijk Nagoer zijn grenzen of machtssfeer veel verder uitgestrekt zou hebben dan tot Dolok Silo, Poerba, Raja en Panē. Nagoer kan hier geheerscht hebben, het kan ook daar een kolonie gehad hebben. Deze veronderstelling is niet zoo geheel gewaagd, omdat aan de overzijde der rivier ook een kolonie uit het Siantarsche gelegen moet hebben, n.l. Bangoen Moelia, welks inwoners na een aardbeving, zich in het tegenwoordige Batoekarang gevestigd hebben. Deze behooren ook tot de Peranginangin en noemen zich naar het verwoeste dorp Bangoen. Zij behooren dus tot denzelfden Perangin-anginstam als de P. Mano.

Hoe de P. Mano verdwenen zijn zegt ons verhaal niet, maar er zijn wel meer stammen verdwenen, zooals ons het verhaal Beroe Ginting Pasē leert. En de nabijheid van de Simbiringdorpen Sarinembah en Perbesi doet ons denken, dat de Simbirings daar misschien ook de hand in gehad hebben.

Raja, Februari 1926.

J. H. NeumanN. 